\title{
Carbon pool ratios as scientific support to field morphology in the differentiation of
}

\section{dark subsurface soil horizons}

\author{
Maíra Akemi Toma ${ }^{1}$, Phillip Ray Owens ${ }^{2}$, Carlos Alberto Silva ${ }^{1}$, Sérgio Henrique Godinho Silva ${ }^{1}$, Elen Alvarenga Silva ${ }^{3}$, Nilton Curi ${ }^{1 *}$
}

${ }^{1}$ Federal University of Lavras - Dept. of Soil Science Campus Universitário, C.P. 3037 - 37200-000 - Lavras, MG - Brazil.

2Purdue University - Dept. of Agronomy, C.P. 47907 - West Lafayette, IN - USA.

${ }^{3}$ Federal University of Paraná - Dept. of Soils and Agricultural Engineering - 80035-050 - Curitiba, PR Brazil.

*Corresponding author <niltcuri@dcs.ufla.br>

Edited by: Tairone Paiva Leão

Received July 30, 2014

Accepted December 10, 2014
ABSTRACT: In soil surveys, it is usual to find profiles with an uncommon disposition of horizons. Dark horizons in depth might be either the consequence of erosion and redeposition of soil materials from upslope or an indication of the podzolization process, which forms a spodic horizon. Few laboratory analyses are known to characterize dark subsurface horizons which could allow for the differentiation of spodic from buried A horizons. Some researchers propose C-humic and C-fulvic acid fraction ratios and forms of carbon to analyze characteristics of these horizons. Therefore, this research aimed to characterize dark subsurface horizons found in soils under a Eucalyptus minimum tillage system in the state of Rio Grande do Sul, Brazil, and to relate soil organic carbon to landscape features in toposequences. The characterization was performed by using the following ratios: humic acid and fulvic acid fractions (Cha/Cfa); pyrophosphate extractable-C and organic carbon $(\mathrm{Cp} / \mathrm{OC})$; fulvic acid fraction and pyrophosphate extractable- $\mathrm{C}$ $(\mathrm{Cfa} / \mathrm{Cp})$, and fulvic acid fraction and organic carbon $(\mathrm{Cfa} / \mathrm{OC})$. Soil organic carbon was related to slope gradient and Geomorphons in a Geographic Information System (GIS). None of the horizons analyzed met the criteria required for spodic horizon classification, where $\mathrm{Cha} / \mathrm{Cfa}<$ $0.50, \mathrm{Cfa} / \mathrm{OC}<0.30$, and the ratio $\mathrm{Cp} / \mathrm{OC} \geq 0.50$ simultaneously with $\mathrm{Cfa} / \mathrm{Cp} \geq 0.50$. A relationship was found between landscape features and soil organic carbon content. The methodology proved to be satisfactory for providing scientific support to field morphology classification of dark subsurface horizons, specifically in the case where they could be misinterpreted as spodic horizons.

Keywords: humic substances, organic matter, erosion, podzolization, redeposition

\section{Introduction}

Soil surveys identify, classify and map soils within an area of interest to support decisions regarding their proper use and management for forestry or agricultural crops. Fieldwork is an essential part of any soil survey, and its association with Geographic Information Systems (GIS) and spatial data availability has improved soil survey results (Menezes et al., 2013). This allows for better understanding of relationships between landforms, such as those identified by the digital soil mapping tool called Geomorphons (Jasiewicz and Stepinski, 2013), and soil properties, for example soil organic matter content (Qin et al., 2012). Thus, soil data can be spatialized to non-sampled places, and help to predict soil properties, especially in larger and/or difficult to access areas.

In Brazil, 4.7 out of 6.5 million hectares of cultivated forests consist of Eucalyptus plantations and its commercial production generated around 26.5 billion dollars and 4 million jobs in 2011 (ABRAF, 2012). In addition to its economic benefits, Eucalyptus has played an important role in environmental issues in the effort to recover degraded areas, reduce soil erosion, and increase nutrient cycling, as well as boosting $\mathrm{C}-\mathrm{CO}_{2}$ sequestration from the atmosphere (Avanzi et al., 2011).

During soil surveys in the state of Rio Grande do Sul (RS), Brazil, subsurface dark horizons have been identified in Eucalyptus plantations (Silva et al., 2012b) which could be mistaken at first as spodic horizons, since they are both dark and found in deeper soil layers. Furthermore, differentiation between them may be somewhat uncertain because only a few laboratory analyses are known to characterize dark subsurface horizons, and spodic horizons have been basically classified in the Brazilian Soil Classification System according to field morphology.

To determine more precisely the occurrence of either a spodic horizon or a buried A horizon, McKeague (1968) and Ito et al. (1991) proposed ratios involving organic carbon (OC), humic acid fraction (Cha), fulvic acid fraction $(\mathrm{Cfa})$, and pyrophosphate-extractable $\mathrm{C}$ (Cp). Thus, as pointed out by Ito et al. (1991), these ratios in various combinations (OC, Cha, Cfa and $\mathrm{Cp}$ ) should present a reliable criterion for separating spodic from buried A horizons.

This study was carried out in order to characterize carbon pools in soils under Eucalyptus plantations, which enable the differentiation of spodic from buried A horizons, providing scientific support to field morphology and soil classification, and to relate soil organic carbon to landscape features in toposequences. The field hypotheses were that the dark subsurface horizons are buried A horizons resulted from erosion and redeposition of soils from upslope rather than originated from the process of podzolization, and landform analyses of the toposequences can help to estimate soil organic carbon content in non-sampled areas. 


\section{Materials and Methods}

\section{Study areas and field sampling}

This study was performed in areas under Eucalyptus plantations in the state of Rio Grande do Sul, Brazil. According to the Köppen climatic classification, the climate is Cfa, humid, without dry periods, with an annual average precipitation of $1,500 \mathrm{~mm}$; the mean temperature ranges from $22{ }^{\circ} \mathrm{C}$ in the warmer periods to $3{ }^{\circ} \mathrm{C}$ in the colder periods. Soil samples were collected from three forest stands named Terra Dura $\left(51^{\circ} 36^{\prime} 43.09^{\prime \prime}\right.$ W, $30^{\circ} 10^{\prime} 29.56$ " $\left.\mathrm{S}\right)$, Canafistula $\left(52^{\circ} 14^{\prime} 48.38^{\prime \prime} \mathrm{W}, 30^{\circ} 24^{\prime} 91.10\right.$ "S), and Sanga das Pedras $\left(52^{\circ} 22^{\prime} 33.74^{\prime \prime}\right.$ W, 30 $10^{\circ} 48.39^{\prime \prime}$ S) (Figure 1), the first one being located in Eldorado do Sul and the others in Pantano Grande, all of them in RS. Each forest stand was different in terms of previous use and date of implantation, but similar with regard to the presence of a dark subsurface horizon (Table 1).

The soil samples were collected in a toposequence (footslope, lower backslope, upper backslope, summit), at three depths, $0-5 \mathrm{~cm}, 5-20 \mathrm{~cm}$ and $20-40 \mathrm{~cm}$, according to the following parameters of horizon identification: darkened forming A horizon, yellowish intermediate horizon and darkened subsurface horizon, respectively. The samples were air-dried and passed through a $2 \mathrm{~mm}$ sieve prior to being submitted for laboratory analyses. Next, laboratory analyses of organic carbon (OC), fulvic (Cfa) and humic (Cha) acid fractions, and pyrophosphate extractable carbon $(\mathrm{Cp})$ were performed in order to classify the darkened subsurface horizon found in the three Eucalyptus stands categorized as either spodic or buried A horizon, according to McKeague (1968) and Ito et al. (1991).

\section{Organic carbon analysis}

To determine organic carbon content, the Yeomans and Bremner (1988) method was used. Thus, $300 \mathrm{mg}$ of air-dried soil were weighed in glass tubes into which 5.0 $\mathrm{mL}$ of potassium dichromate $\left(\mathrm{K}_{2} \mathrm{Cr}_{2} \mathrm{O}_{7}\right)\left(0.167 \mathrm{~mol} \mathrm{~L}^{-1}\right)$ and $10.0 \mathrm{~mL}$ of concentrated sulfuric acid $\left(\mathrm{H}_{2} \mathrm{SO}_{4}\right)$ were

Table 1 - Previous use and management system of the forest stands studied.

\begin{tabular}{|c|c|c|c|c|c|c|}
\hline Eucalyptus stand & Eucalyptus planting year & Management system & Planting fertilization & Liming & Cover fertilization & Previous use \\
\hline Terra Dura & 2001 & Reform & $\begin{array}{c}100 \text { g per plant NPK } \\
06: 30: 06\end{array}$ & $2000 \mathrm{~kg} \mathrm{ha}^{-1}$ & $\begin{array}{c}200 \mathrm{~kg} \mathrm{ha}^{-1} \mathrm{NPK} \\
15: 05: 30\end{array}$ & $\begin{array}{c}\text { - Paspalum notatum } \\
\text { (native pasture) } \\
\text { - Agricultural cultivation } \\
\text { - Acacia decurrens plantation }\end{array}$ \\
\hline Canafistula & 1998 & Regrowth & $\begin{array}{c}100 \text { g per plant NPK } \\
06: 30: 06\end{array}$ & - & $\begin{array}{c}200 \mathrm{~kg} \mathrm{ha}^{-1} \mathrm{NPK} \\
15: 05: 30\end{array}$ & $\begin{array}{c}\text { - Eryngium horridum } \\
\text { (native pasture) } \\
\text { - Acacia decurrens plantation }\end{array}$ \\
\hline Sanga das Pedras & 2003 & Regrowth & $\begin{array}{c}100 \text { g per plant NPK } \\
04: 14: 18\end{array}$ & - & - & $\begin{array}{l}\text { - Eragrostis plana } \\
\text { (planted pasture) } \\
\text { - Soybean plantation }\end{array}$ \\
\hline
\end{tabular}

Adapted from Silva et al. (2012b).

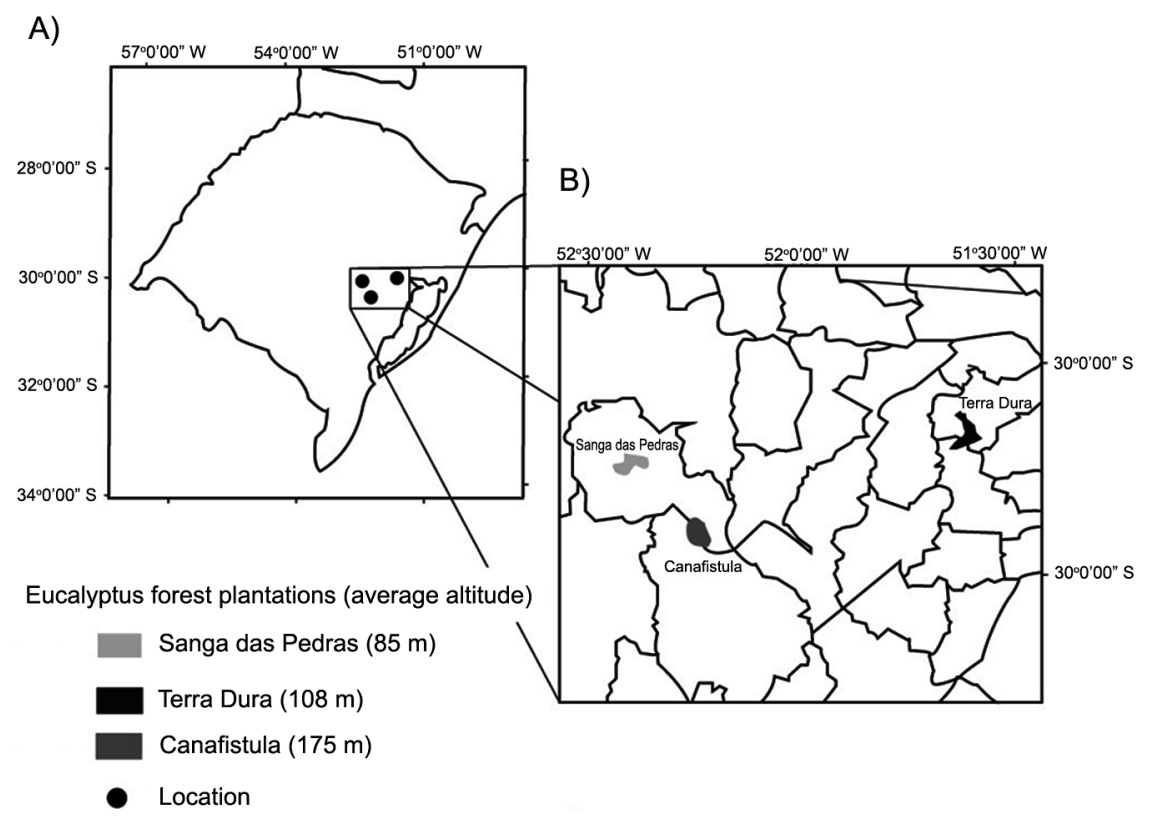

Figure 1 - Location of: A) state of Rio Grande do Sul; and B) the Eucalyptus plantations areas sampled. 
added. The tubes were placed on a digestion block at 170 ${ }^{\circ} \mathrm{C}$ for $30 \mathrm{~min}$. After cooling, the contents were transferred to Erlenmeyer flasks and $5.0 \mathrm{~mL}$ of phosphoric acid $\left(\mathrm{H}_{3} \mathrm{PO}_{4}\right)$ and three drops of diphenylamine indicator (1 $\%)$ were added. In sequence, the digested samples were titrated with iron sulfate solution $\left(\mathrm{FeSO}_{4}\right)\left(0.4 \mathrm{~mol} \mathrm{~L}^{-1}\right)$.

An analysis of the terrain in a Geographic Information System (GIS) environment was performed to relate the landform to the OC content at the three Eucalyptus stands. This procedure could assist in predicting this soil attribute in non-sampled areas. For this purpose, a Digital Elevation Model (DEM) was constructed in a GIS environment from contour lines at a scale of 1:10,000 and $5 \mathrm{~m}$ of vertical distance between them, produced from a planialtimetric survey, using the Topo to Raster function of the ArcGIS 9.3 (ESRI) software. The DEM and some terrain maps derived from it, such as slope gradient and a representation of the landform named Geomorphons (Jasiewicz and Stepinski, 2013), a mapping tool that identifies landforms within a landscape, were compared with the OC content. This could help to better understand soil property variability across the study areas, and support soil classification and management.

\section{Fractionation of humic substances}

Humic substances represent the major portion of carbon found in soils. Humic (soluble in alkaline solutions and precipitated in acidic medium) and fulvic (soluble both in acidic and alkaline solutions) fractions are stabilized organic materials that play different roles in soils, since they help to increase cation exchange capacity, water retention, and improve soil structure. They are also complexing agents of both inorganic and organic chemical species, among other functions (Stevenson, 1994; Schnitzer, 2000).

Humic and fulvic acid ratios are indicative of the land use system, since the distribution of $\mathrm{C}$ among humic fractions changes when forest soil is converted to crop areas, with a predominance of fulvic acid in relation to humic acid in cultivated areas (Guimarães et al., 2013). The distribution of $\mathrm{C}$ in humic substances is also an index that will distinguish the C-rich diagnostic horizon found in tropical soil profiles (Fontana et al., 2008).

To fractionate humic substances, an adaptation of the Benites et al. (2003) method was used. In centrifuge tubes, $1.0 \mathrm{~g}$ of soil was weighed and mixed with $10.0 \mathrm{~mL}$ of sodium hydroxide $(\mathrm{NaOH})\left(0.1 \mathrm{~mol} \mathrm{~L}^{-1}\right)$. The tubes were manually shaken for $30 \mathrm{~s}$ and left resting for $24 \mathrm{~h}$ in order to allow solid particles to settle. In sequence, soil samples were centrifuged at $18,109 \mathrm{x}$ g for $10 \mathrm{~min}$, and the supernatant was transferred to other tubes. After repeating the already described steps $10.0 \mathrm{~mL}$ of sodium hydroxide $(\mathrm{NaOH})\left(0.1 \mathrm{~mol} \mathrm{~L}^{-1}\right)$ was added to the tubes, which were manually shaken for $30 \mathrm{~s}$ and left resting for one hour. Next, they were centrifuged at $18,109 \times \mathrm{g}$ for $10 \mathrm{~min}$. The supernatant was placed together with the supernatant previously recovered. The residues were dried in a lyophilizer. To the supernatants stored, $2.0 \mathrm{~mL}$ of sulfuric acid $\left(\mathrm{H}_{2} \mathrm{SO}_{4}\right)(20 \%)$ was added, until they reached $\mathrm{pH} 2$. The samples were left to rest for $18 \mathrm{~h}$, when the humic acid was decanted. The supernatants were filtered through a $0.45 \mathrm{~mm}$ membrane in a vacuum system. The filtered supernatants (fulvic acid fraction) were recovered and the volume was topped up to $50 \mathrm{~mL}$ using distilled water. The humic acid fraction attached to the filter was washed with $\mathrm{NaOH} 0.1 \mathrm{~mol}$ $\mathrm{L}^{-1}$ and the volume was also topped up to $50 \mathrm{~mL}$ using distilled water.

\section{$\mathrm{C}$ in fulvic and humic fractions}

To determine the carbon content in fulvic and humic acid fractions, a $5.0 \mathrm{~mL}$ aliquot of the solutions was obtained by the previous method and transferred to digestion tubes. Then, $1.0 \mathrm{~mL}$ of potassium dichromate $\left(\mathrm{K}_{2} \mathrm{Cr}_{2} \mathrm{O}_{7}\right)\left(0.042 \mathrm{~mol} \mathrm{~L}^{-1}\right)$ and $5.0 \mathrm{~mL}$ of concentrated $\mathrm{H}_{2} \mathrm{SO}_{4}$ were added to the samples and to six digestion tubes with $5.0 \mathrm{~mL}$ of distilled water (blank samples). The tubes were digested for $30 \mathrm{~min}$ at $150{ }^{\circ} \mathrm{C}$ in a digestion block (three blank samples were saved). In sequence, samples were transferred to $250 \mathrm{~mL}$ Erlenmeyer flasks and the volume was topped up to $50 \mathrm{~mL}$ with distilled water. An amount of $0.3 \mathrm{~mL}$ of ferroin indicator was added to each tube and the samples were titrated with ammonium iron sulfate $\left(\left(\mathrm{NH}_{4}\right)_{2} \mathrm{Fe}\left(\mathrm{SO}_{4}\right)_{2}, 6 \mathrm{H}_{2} \mathrm{O}\right)\left(0.0125 \mathrm{~mol} \mathrm{~L}^{-1}\right)$.

\section{Pyrophosphate extractable C}

In spodic horizons, a diagnostic feature is the presence of amorphous colloidal humus and sesquioxides of high cation exchange capacity, which are active compounds (Bascomb, 1968). These compounds can be separated from inactive compounds through a simple extraction technique that employs pyrophosphate solutions. To extract both humified organic matter and the metal ions associated with organic matter in soils, pyrophosphate solution has been used in attempts to develop more precise criteria for characterizing and classifying soils (McKeague, 1968). In an alkaline solution, pyrophosphate extracts organic matter (pyrophosphate extractable C) as it is more soluble, whereas crystalline inorganic $\mathrm{Fe}$ compounds are less soluble (Bascomb, 1968). Therefore, in this study, sodium pyrophosphate, an alkaline solution, was chosen to extract $\mathrm{C}$ and relate it to organic carbon and the fulvic acid fraction aiming to distinguish spodic from non-spodic horizons.

To determine the pyrophosphate extractable C, an adaptation of the method described by Rayment and Lyons (2011) was used. In a $250 \mathrm{~mL}$ centrifuge tube, $1.0 \mathrm{~g}$ of air-dried soil (<2 mm) and $100 \mathrm{~mL}$ of sodium pyrophosphate solution $\left(\mathrm{Na}_{4} \mathrm{P}_{2} \mathrm{O}_{7} \cdot 10 \mathrm{H}_{2} \mathrm{O}\right)$ (44.61 $\mathrm{g} \mathrm{L}^{-1}$ ) were added together, and the mixture was continuously shaken in an end-over-end shaker for 16 hours. Then, five drops of superfloc solution (polyacrylamide $\left(\left(\mathrm{C}_{3} \mathrm{H}_{5} \mathrm{NO}\right)\right.$ n) from Sigma-Aldrich Co. LLC. $)\left(2 \mathrm{~g} \mathrm{~L}^{-1}\right)$ were added to the tubes which were vigorously shaken for $30 \mathrm{~s}$. After, the samples were centrifuged for $30 \mathrm{~min}$ at 10,000 
rpm to free the extracts from very fine soil particles. Afterwards, $10 \mathrm{~mL}$ of the extracts were transferred to a $50 \mathrm{~mL}$ beaker. The content was evaporated down to a low volume in an incubator at $60{ }^{\circ} \mathrm{C}$. An aliquot of 1 $\mathrm{mL}$ of the concentrated fluid was transferred to a LECO crucible, and the carbon content determined by LECO TruMac CN. The values of carbon content obtained from LECO were corrected to a ratio of $1: 100$ ratio of the initial pyrophosphate extract and the $10.0 \mathrm{~mL}$ aliquot taken.

\section{Dark subsurface horizons classification and statistical analysis}

According to the results of $\mathrm{OC}, \mathrm{Cha}, \mathrm{Cfa}$ and $\mathrm{Cp}$, the ratios between them were calculated in order to classify the dark subsurface horizon as buried A or spodic, as suggested by McKeague (1968) and Ito et al. (1991). The former suggested that a spodic horizon should have Cha/ $\mathrm{Cfa}<0.50$ or $\mathrm{Cfa} / \mathrm{OC}<0.30$ to be a spodic horizon, while the latter stated that $\mathrm{Cp} / \mathrm{OC} \geq 0.50$ and $\mathrm{Cfa} / \mathrm{Cp}$ $\geq 0.50$ ratios occuring simultaneously characterize a spodic horizon. Otherwise, they should be classified as a buried A horizon. Those were the parameters used for classifying the Eucalyptus dark subsurface horizons in this study.

Statistical analysis was performed for each class of depth at the Eucalyptus stands, to quantify the effect of the relief on the soil attributes analyzed. A completely randomized design was used and treatment means were compared by Scott-Knott at a probability of $5 \%$ using the SISVAR software version 5.3 (Ferreira, 2014).

\section{Results and Discussion}

\section{Soil carbon fractions}

Table 2 presents the results of the organic carbon $(\mathrm{OC})$, carbon in fulvic (Cfa) and humic acid (Cha) fractions and pyrophosphate extractable carbon $(\mathrm{Cp})$ found at each depth sampled, for evaluating the behavior of these $\mathrm{C}$ fractions under different Eucalyptus stands. Cha is characterized by higher levels at the $0-5 \mathrm{~cm}$ depth horizon in comparison with other soil depths, under all the evaluated conditions. Mirave and Orioli (1987) stated that this form of carbon is less mobile in soil due to its low solubility in water, which makes it accumulate in the surface soil horizons. Furthermore, under most conditions, Cha is higher in the subsurface darkened horizon $(20-40 \mathrm{~cm})$ than in the intermediate yellowish horizon $(5-20 \mathrm{~cm})$, which is indicative of more similarities between this deeper horizon to the A horizon $(0-5 \mathrm{~cm})$. On the other hand, $\mathrm{Cfa}$, in most cases, decreased with depth.

Carbon (\%) extracted by pyrophosphate solution, in general, was highest at $0-5 \mathrm{~cm}$ and lowest at $5-20 \mathrm{~cm}$ depth. Although the $20-40 \mathrm{~cm}$ horizon had more Cp than at the $5-20 \mathrm{~cm}$ horizon, this increase was not higher than $\mathrm{Cp}$ found at 0-5 cm. Bascomb (1968), analyzing Cp in depth of many soils from England and Wales, observed two patterns: Cp decreasing with depth (most soils); and soils which presented the highest $\mathrm{Cp}$ contents in the B horizon (Spodosols). Thus, the soils from the three Eucalyptus stands had an increase of Cp in the 20-40 cm horizon. However, this $\mathrm{Cp}$ content was not the highest content considering the whole profile, and they followed a different pattern from the soils studied by Bascomb (1968).

Table 2 - Soil carbon and carbon as humic and fulvic acid fractions, and carbon extracted by pyrophosphate in the Eucalyptus stands.

\begin{tabular}{|c|c|c|c|c|c|c|c|c|c|c|c|c|}
\hline \multirow{3}{*}{$\begin{array}{l}\text { Soil depth } \\
(\mathrm{cm})^{1}\end{array}$} & \multicolumn{12}{|c|}{ Eucalyptus Stands } \\
\hline & \multicolumn{4}{|c|}{ Terra Dura } & \multicolumn{4}{|c|}{ Canafistula } & \multicolumn{4}{|c|}{ Sanga das Pedras } \\
\hline & $\mathrm{OC}^{2}$ & $\mathrm{Cfa}^{3}$ & $\mathrm{Cha}^{4}$ & $\mathrm{Cp}^{5}$ & $\mathrm{OC}$ & $\mathrm{Cfa}$ & Cha & $\mathrm{Cp}$ & $\mathrm{OC}$ & $\mathrm{Cfa}$ & Cha & $\mathrm{Cp}$ \\
\hline & \multirow{2}{*}{\multicolumn{12}{|c|}{ Footslope (FT) }} \\
\hline & & & & & & & & & & & & \\
\hline $0-5$ & $2.47 \mathrm{a}$ & $0.30 \mathrm{a}$ & $0.55 \mathrm{a}$ & $0.63 a$ & $2.89 \mathrm{a}$ & $0.47 \mathrm{a}$ & $0.78 \mathrm{a}$ & $0.55 a$ & $3.07 \mathrm{a}$ & $0.45 \mathrm{a}$ & $0.58 \mathrm{a}$ & $0.49 c$ \\
\hline $5-20$ & $1.43 b$ & $0.27 b$ & $0.28 \mathrm{c}$ & $0.35 b$ & $2.01 \mathrm{~b}$ & $0.10 \mathrm{~b}$ & $0.29 b$ & $0.43 b$ & $1.75 \mathrm{~b}$ & $0.23 b$ & $0.37 c$ & $0.72 b$ \\
\hline \multirow[t]{2}{*}{$20-40$} & $1.10 \mathrm{c}$ & $0.22 \mathrm{c}$ & $0.30 \mathrm{~b}$ & $0.33 c$ & $0.78 \mathrm{c}$ & $0.07 c$ & $0.26 c$ & $0.30 \mathrm{c}$ & $1.55 \mathrm{c}$ & $0.21 \mathrm{c}$ & $0.48 b$ & $1.04 \mathrm{a}$ \\
\hline & \multicolumn{12}{|c|}{ Lower Backslope (LB) } \\
\hline 0-5 & $2.47 a$ & $0.39 a$ & $0.58 \mathrm{a}$ & $0.58 \mathrm{~b}$ & $9.56 \mathrm{a}$ & $0.87 a$ & $1.70 \mathrm{a}$ & $0.80 a$ & $11.59 \mathrm{a}$ & $0.90 \mathrm{a}$ & $2.29 \mathrm{a}$ & $0.82 c$ \\
\hline $5-20$ & $1.40 \mathrm{~b}$ & $0.27 b$ & $0.37 \mathrm{c}$ & $0.52 c$ & $1.59 \mathrm{c}$ & $0.35 \mathrm{c}$ & $0.33 c$ & $0.37 c$ & $1.64 \mathrm{~b}$ & $0.26 b$ & $0.29 c$ & $1.13 \mathrm{a}$ \\
\hline \multirow[t]{2}{*}{$20-40$} & $1.40 \mathrm{~b}$ & $0.17 c$ & $0.44 \mathrm{~b}$ & $0.62 \mathrm{a}$ & $1.77 \mathrm{~b}$ & $0.41 b$ & $0.44 \mathrm{~b}$ & $0.48 b$ & $1.34 \mathrm{c}$ & $0.21 \mathrm{c}$ & $0.40 \mathrm{~b}$ & $0.91 \mathrm{~b}$ \\
\hline & \multicolumn{12}{|c|}{ Upper Backslope (UB) } \\
\hline 0-5 & $3.40 \mathrm{a}$ & $0.43 a$ & $0.74 \mathrm{a}$ & $0.58 a$ & $12.84 \mathrm{a}$ & $0.92 \mathrm{a}$ & $2.22 \mathrm{a}$ & $0.97 a$ & 9.14 a & $0.97 a$ & $1.70 \mathrm{a}$ & $2.73 \mathrm{a}$ \\
\hline $5-20$ & $1.62 \mathrm{~b}$ & $0.39 b$ & $0.24 c$ & $0.41 \mathrm{c}$ & $1.25 \mathrm{~b}$ & $0.18 b$ & $0.21 \mathrm{c}$ & $0.25 c$ & $1.31 \mathrm{~b}$ & $0.24 \mathrm{c}$ & $0.24 b$ & $0.93 b$ \\
\hline $20-40$ & $1.49 \mathrm{c}$ & $0.37 c$ & $0.31 \mathrm{~b}$ & $0.49 \mathrm{~b}$ & $1.09 \mathrm{c}$ & $0.17 \mathrm{~b}$ & $0.31 \mathrm{~b}$ & $0.34 \mathrm{~b}$ & $1.18 \mathrm{c}$ & $0.27 \mathrm{~b}$ & $0.14 b$ & $0.54 \mathrm{c}$ \\
\hline & \multicolumn{12}{|c|}{ Summit (S) } \\
\hline 0-5 & $3.37 \mathrm{a}$ & $0.55 a$ & $0.75 a$ & $0.42 \mathrm{a}$ & $11.52 \mathrm{a}$ & $0.72 \mathrm{a}$ & $1.80 \mathrm{a}$ & $0.88 a$ & $3.74 \mathrm{a}$ & $0.51 \mathrm{a}$ & $0.85 a$ & $0.51 \mathrm{a}$ \\
\hline $5-20$ & $1.21 \mathrm{c}$ & $0.23 c$ & $0.29 c$ & $0.32 \mathrm{c}$ & $2.09 \mathrm{~b}$ & $0.36 \mathrm{~b}$ & $0.57 \mathrm{~b}$ & $0.33 c$ & $1.71 \mathrm{~b}$ & $0.32 \mathrm{~b}$ & $0.31 \mathrm{~b}$ & $0.32 b$ \\
\hline $20-40$ & $1.73 \mathrm{~b}$ & $0.28 b$ & $0.36 b$ & $0.37 \mathrm{~b}$ & $1.75 \mathrm{c}$ & $0.34 \mathrm{c}$ & $0.28 \mathrm{c}$ & $0.44 \mathrm{~b}$ & $0.93 c$ & $0.19 c$ & $0.15 c$ & $0.19 c$ \\
\hline
\end{tabular}

${ }^{1}$ Samples were collected with three replicates at each depth; ${ }^{2} \mathrm{OC}=$ organic carbon; ${ }^{3} \mathrm{Cfa}=$ carbon in fulvic acid; ${ }^{4} \mathrm{Cha}=\mathrm{carbon}$ in humic acid; ${ }^{5} \mathrm{Cp}=\mathrm{pyrophosphate}$ extractable carbon. Values followed by the same letter within the same condition (landscape position and content of OC, Cfa or Cha) do not differ (Tukey test, $p<$ 0.05). 
In the Terra Dura Eucalyptus stand, the lowest amounts of OC were found in the $0-5 \mathrm{~cm}$ depth horizon, which may be associated with its condition at the time the soil samples were collected (reform) and due to its previous uses (livestock, agricultural cultivation and Acacia decurrens). This may have promoted more soil turnover, which probably led to increases in the organic matter decomposition rates (Kosmas et al., 2000; Lal, 2004) and consequent losses due to water erosion.

Regarding the toposequences, in both Terra Dura and Canafistula Eucalyptus stands, the amount of OC at $0-5 \mathrm{~cm}$ depth on the landscape positions were in part closely related to the landforms (Figure 2). Using the Geomorphons and the slope gradient at the sample locations, it was noticed that, in Terra Dura, the lower backslope (LB) and summit (S) landscape positions are within the same landform type (spur), which is more convex and promotes more losses than accumulations. However, LB is on a steeper slope gradient than S, which may be associated with a lower amount of $\mathrm{OC}$ found in that steep condition. The same pattern occurs in footslope (FT) and upper blackslope (UB): both are included in the Geomorphons feature named slope, corresponding to a linear landform, but FT is on a steeper slope gradient than UB, this latter containing more OC.

In Canafistula Eucalyptus stand, the smallest amount of OC was found in FT (3\%), which is included in the spur landform, according to Geomorphons, and presents a $35 \%$ slope condition. UB and $\mathrm{S}$, which are also on spur landform, but under $22 \%$ and $23 \%$ slope conditions, respectively, contains much more OC (12 $\%$ in $\mathrm{S}$ and $13 \%$ in UB) than the FT, probably due to the gentler relief. For both UB and $S$, the similar landscape conditions may have contributed to the similar OC amounts in both places. LB is on slope landform and $10 \%$ slope gradient, containing less OC than the spur conditions, but more than FT, which is on the same landform, but on a steeper slope place.

Among the study areas, only in Sanga das Pedras Eucalyptus stand it was not possible to capture proper
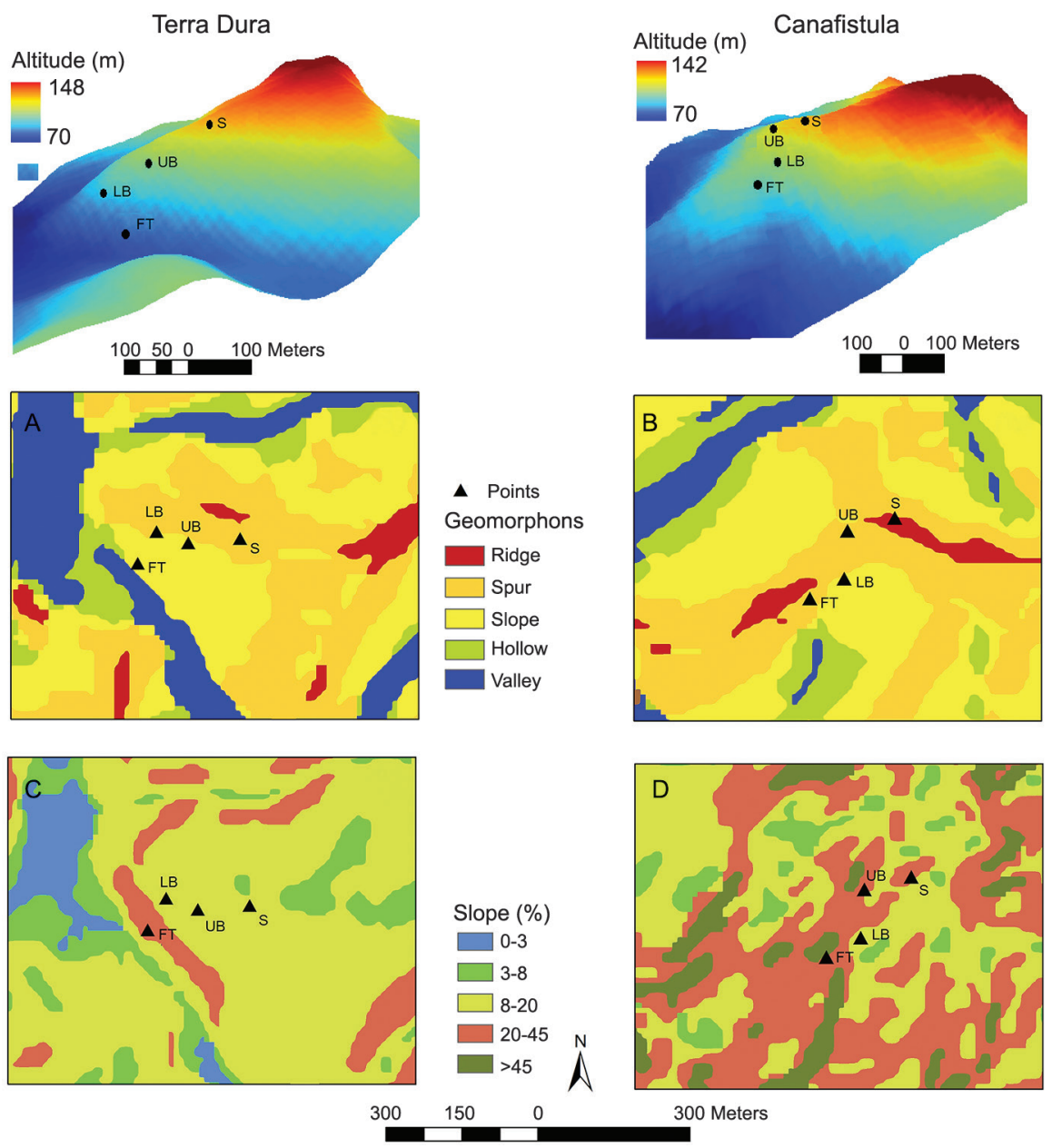

Figure 2 - Elevation, Geomorphons (A) and (B) and slope gradient (C) and (D) for Terra Dura and Canafistula Eucalyptus stands. FT: footslope; LB: lower backslope; UB: upper backslope; and S: summit. 
relationships between landscape position and amount of $\mathrm{OC}$, indicating that other factors rather than topography, may have been influencing the amount of OC. However, in agreement with the trends found in Terra Dura and Canafistula Eucalyptus stands, many researchers have found a correlation between organic carbon and landscape position (Broek et al., 1981; Kreznor et al.,1989). These relationships have been captured by digital soil mapping tools (Moore et al., 1993; Mueller and Pierce, 2003; Hancock et al., 2010; Pei et al., 2010) since they promote a better overview of soil types and properties variability along the landscape.

\section{Differentiation of spodic from buried A horizons}

The 20-40 cm depth column was the basis for analyzing the darkened subsurface horizons (Figures 3, 4, and 5). Although in most cases the ratios of $\mathrm{Cfa} / \mathrm{Cp}$ obtained for all the Eucalyptus stands were higher than 0.5, none of them simultaneously presented Cp/OC higher than 0.5, which is the condition required to classify the subsurface horizon as spodic, according to Ito et al. (1991). In Sanga das Pedras stand, at FT and LB landscape positions, although the ratio $\mathrm{Cp} / \mathrm{OC}$ reached the limit established by Ito et al. (1991), Cfa / Cp ratios were lower than the threshold value (0.5). Furthermore, the ratios established by McKeague (1968) (Cha / Cfa < 0.5 or $\mathrm{Cfa} / \mathrm{OC}<0.3$ ) to characterize spodic horizon were not achieved in any of the three Eucalyptus stands investigated. Therefore, all the darkened subsurface horizons should be classified as buried A horizons, in agreement with field observations and measurements.

The formation of buried A horizons can be due to many circumstances, and, according to Chaopricha and Marín-Spiotta (2014), there are multiple factors related to pedogenesis, biota and geomorphology that contribute to the occurrence of horizons with increased organic carbon storage in subsoil layers. Geomorphology processes may cause eroded sediments from upslope to accumulate in the lower landscape positions, burying the soil in these locations where it becomes more stabilized (Berhe and Kleber, 2013). Furthermore, some management practices that enhance erosion rates, such as nonadequate soil tillage operations (Govers et al., 1999), can induce burial of soils, reflecting the conditions described and measured in the field, according to the soil surveys performed in the studied Eucalyptus areas studied.

The capability of $\mathrm{C}$ to remain stored at depth for a long time is a relevant factor. Decomposition is decreased under those conditions as a consequence of decreased microbial biomass and activity in areas with low oxygen diffusion (Chaopricha and Marín-Spiotta, 2014), and increased soil wetness (Gregorich et al.,


Figure 3 - Ratios among carbon extracted by pyrophosphate (Cp), carbon in humic acid (Cha), carbon in fulvic acid (Cfa) and organic carbon (OC) influenced by landscape position and soil depth in Terra Dura Eucalyptus stand. FT: footslope; LB: lower backslope; UB: upper backslope; and S: summit. Dash line establishes the limit between spodic and non-spodic horizon (for spodic horizon, $\mathrm{Cp} / \mathrm{OC} \geq 0.50$ and $\mathrm{Cfa} / \mathrm{Cp} \geq 0.50$, simultaneously, or $\mathrm{Cha} / \mathrm{Cfa}<0.50$ or $\mathrm{Cfa} / \mathrm{OC}<0.30$ ). For each soil depth, the same letters in each column, comparing landscape positions, do not differ (Scott-Knott test, $p<0.05$ ). 

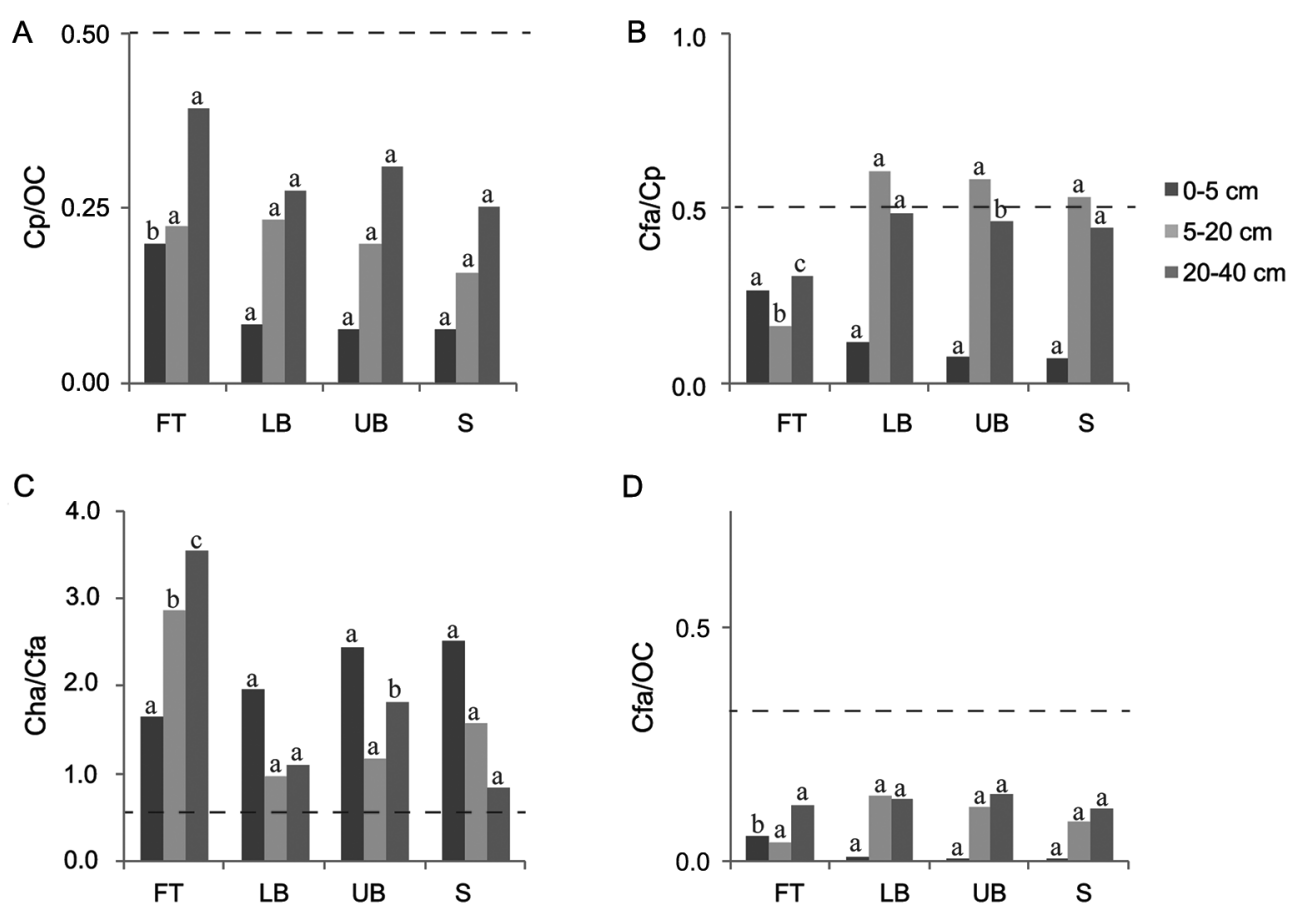

Figure 4 - Ratios among carbon extracted by pyrophosphate (Cp), carbon in humic acid (Cha), carbon in fulvic acid (Cfa) and organic carbon $(\mathrm{OC})$ influenced by landscape position and soil depth in Canafistula Eucalyptus stand. FT: footslope; LB: lower backslope; UB: upper backslope; and S: summit. Dash line establishes the limit between spodic and non-spodic horizon (for spodic horizon, $\mathrm{Cp} / \mathrm{OC} \geq 0.50 \mathrm{and} \mathrm{Cfa} / \mathrm{Cp} \geq 0.50$, simultaneously, or $\mathrm{Cha} / \mathrm{Cfa}<0.50$ or $\mathrm{Cfa} / \mathrm{OC}<0.30$ ). For each soil depth, the same letters in each column, comparing landscape positions, do not differ (Scott-Knott test, $p<0.05$ ).

1998). These facts help to preserve the organic carbon contents at depth and, therefore, it is not uncommon to find buried A horizons in different soils (Doetterl et al., 2012; Vandenbygaart et al., 2012).

\section{Eucalyptus stands soil classification}

As none of the soils studied met the requirements for being classified as Spodosols, these findings are in agreement with the accumulated knowledge concerning soils in the state of RS. Two possible explanations for this trend also support the carbon analyses previously discussed: the low geographical expression of sandy sediments which would contribute to originating Spodosols; and the consequent wide occurrence of Aqualfs in the lowland areas, where Spodosols are more likely to occur. Thus, according to the Soil Taxonomy (US Soil Taxonomy - Soil Survey Staff, 1999), the soils from the Eucalyptus stands were classified as: Rhodudults, in Terra Dura and in Sanga das Pedras; and Dystrudepts, in Canafistula.

With regard to Eucalyptus development, the advantage of this species growing in Ultisols and Inceptisols instead of Spodosols is the capability of those soils to retain more water and make it available to plant roots. For Eucalyptus, water is a crucial factor amongst many others, that affects its performance. This species is very sensitive to anoxic conditions, mainly in the early stag- es of development, when the roots are less capable of pumping water from the soil. In addition, lack of water limits Eucalyptus' growth as it requires high volumes of water and nutrients to attain its minimum height in a short period of time. Therefore, Spodosols would probably be a limitation on Eucalyptus yield, since they are very poor in nutrients and can cause serious problems of water and oxygen deficiency.

In Brazil, Spodosols are highly permeable on the surface horizons (A and E horizons) and impermeable in the spodic B horizon, which is a consequence of a hardened layer commonly formed due to soil genesis (Silva et al., 2012a). Thus, in rainy conditions, these soils can cause anoxia in plant roots. On the other hand, in dry periods the trees can suffer from water deficit.

In general, Ultisols show a special behavior based on their water content: when they are dry, roots can hardly penetrate through the profile, having a tendency to grow horizontally, but when they are moist, roots can go deeper into the soil. However, in RS, the rain is well distributed throughout the year and, for this reason, these soils would not limit root development in Eucalyptus. In addition, Ultisols in the studied areas are the preferred soils for forest cultivation. As regards chemical and physical properties, Inceptisols are intermediate between Spodosols and Ultisols. They are shallow and somewhat gravelly, but richer in nutrients than Spodosols (Schaetzl and Anderson, 2005). 

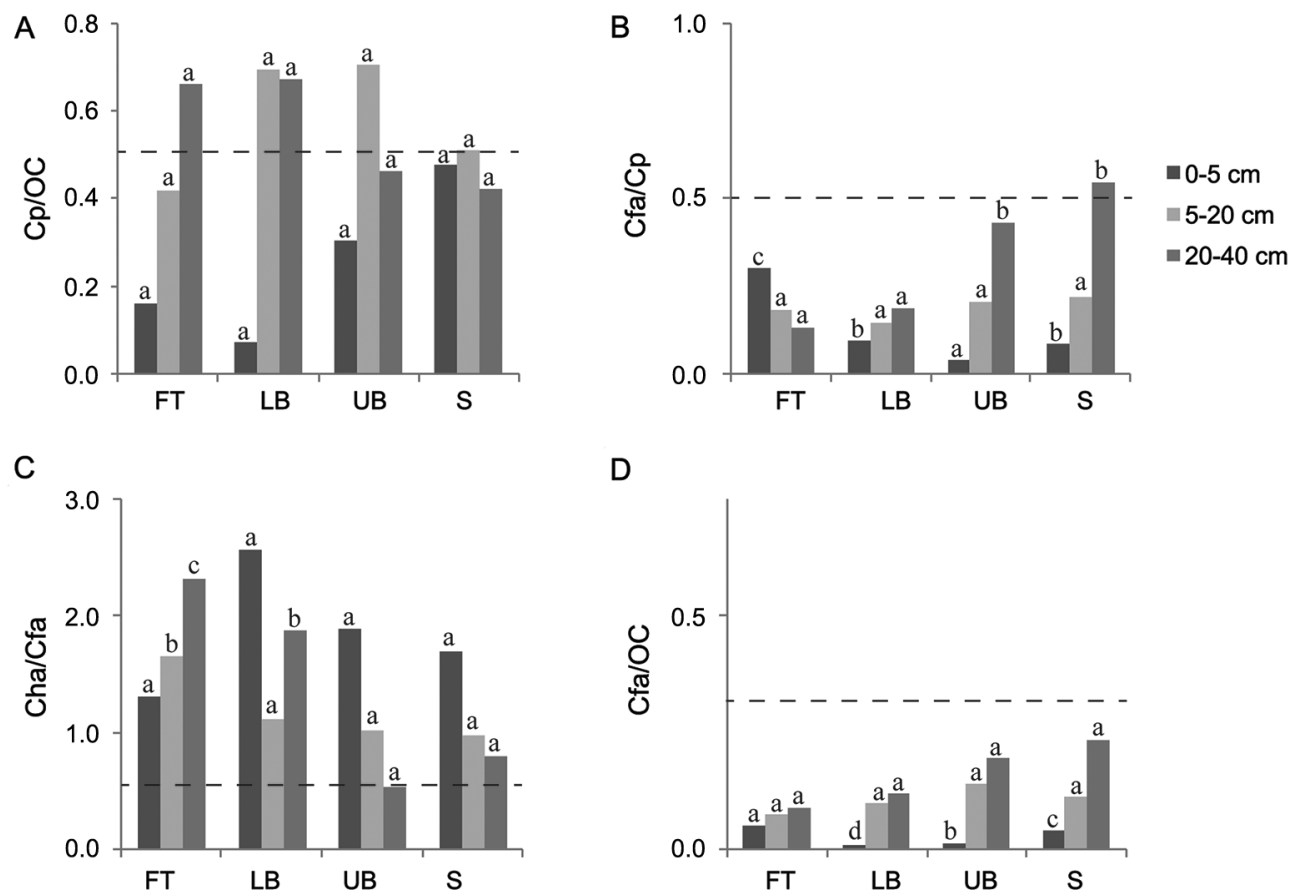

Figure 5 - Ratios among carbon extracted by pyrophosphate (Cp), carbon in humic acid (Cha), carbon in fulvic acid (Cfa) and organic carbon $(\mathrm{OC})$ influenced by landscape position and soil depth in Sanga das Pedras Eucalyptus stand. FT: footslope; LB: lower backslope; UB: upper backslope; and S: summit. Dash line establishes the limit between spodic and non-spodic horizon (for spodic horizon, $\mathrm{Cp} / \mathrm{OC} \geq 0.50$ and $\mathrm{Cfa}$ / $\mathrm{Cp} \geq 0.50$, simultaneously, or $\mathrm{Cha} / \mathrm{Cfa}<0.50$ or $\mathrm{Cfa} / \mathrm{OC}<0.30$ ). For each soil depth, the same letters in each column, comparing landscape positions, do not differ (Scott-Knott test, $p<0.05$ ).

Although morphological criteria are usually adequate for differentiating buried A horizons from spodic horizons, the ratios between carbon humic fractions, as suggested by McKeague (1968) and Ito et al. (1991), are useful for solving controversial cases and, in an unequivocal way, for identifying some of the darkened subsurface horizons, where either erosion and redeposition of soils from upslope or soils formed by podzolization processes occur. Therefore, it is suggested that one additional criterion be added to the Brazilian Soil Classification System to differentiate soils with buried A horizons from spodic horizons, by means of laboratory analysis of organic acids, carbon humic fractions contents and carbon extracted by sodium pyrophosphate solution. These indexes are also reliable attributes for supporting field morphology and soil classification.

\section{Conclusions}

None of the darkened subsurface horizons analyzed met the criteria required to classify them as spodic horizons; thus, the horizons studied in Eucalyptus stands should be classified as buried A horizons. It seems certain enough to confirm the hypothesis that the darkened subsurface horizons investigated are a consequence of erosion and redeposition of soils from the upslope. Carbon fraction ratios and pyrophosphate extractable-C are reliable attributes for supporting soil field morphology and, consequently, for differentiating spodic from buried A horizons.

A relationship was found between soil organic carbon at the $0-5 \mathrm{~cm}$ depth and the landscape form and slope gradient using a GIS. Such tool was adequate for detailing and spatializing sampling site position and the distribution of carbon in the Eucalyptus stands landscape.

\section{Acknowledgments}

The authors thank CNPq, FAPEMIG and CAPES funding agencies for financial support, mainly $\mathrm{CNPq}$ for sponsoring the first author's participation in the Brazilian governmental program known as "Science without Borders", which enabled this project to be developed. We also thank Purdue University and USDA for technical assistance and use of laboratory facilities during the training of the first author.

\section{References}

Associação Brasileira de Produtores de Florestas Plantadas [ABRAF]. 2012. ABRAF's Statistical Yearbook: Base Year 2011. = Anuário Estatístico da ABRAF: Ano Base 2011, ABRAF, Brasília, DF, Brazil. 
Avanzi, J.C.; Norton, L.D.; Silva, M.L.N.; Curi, N.; Oliveira, A.H.; Silva, M.A. 2011. Aggregate stability in soils cultivated with eucalyptus. Pesquisa Agropecuária Brasileira 46: 89-96.

Bascomb, C.L. 1968. Distribution of pyrophosphate-extractable iron and organic carbon in soils of various groups. Journal of Soil Science 19: 251-268.

Benites, V.M.; Mádari, B.; Machado, P.L.O.A. 2003. Extraction and Quantitative Fractionation of Humic Substances in Soil: A Simplified and Low Cost Procedure. $=$ Extração e fracionamento quantitativo de substâncias húmicas do solo: um procedimento simplificado e de baixo custo. Embrapa, Rio de Janeiro, RJ, Brazil. (Comunicado Técnico, 16) (in Portuguese).

Berhe, A.A.; Kleber, M. 2013. Erosion, deposition, and the persistence of soil organic matter: mechanistic considerations and problems with terminology. Earth Surface Processes and Landforms 38: 908-912.

Broek, M. van den; Amstel, A. van; Verbakel, A; Pedroli, B. 1981. Variability of soil properties in a landscape ecological survey in the Tuscan Apennines, Italy. Catena 8: 155-170.

Chaopricha, N.T.; Marín-Spiotta, E. 2014. Soil burial contributes to deep soil organic carbon storage. Soil Biology and Biochemistry 69: 251-264.

Doetterl, S.; Six, J.; Wesemael, B. van; Oost, K. van. 2012. Carbon cycling in eroding landscapes: geomorphic controls on soil organic $\mathrm{C}$ pool composition and $\mathrm{C}$ stabilization. Global Change Biology 18: 2218-2232.

Ferreira, D.F. 2014. Sisvar: a guide for its bootstrap procedure in multiple comparisons. Ciência e Agrotecnologia 38: 109-112.

Fontana, A.; Benites, V.M.; Pereira, M.G.; Anjos, L.H.C. 2008. Humic substances in support of the Brazilian soil classification. Revista Brasileira de Ciência do Solo 32: 20732080 (in Portuguese, with abstract in English).

Govers, G.; Lobb, D.A.; Quine, T.A. 1999. Tillage erosion and translocation: emergence of a new paradigm in soil erosion research. Soil Tillage Research 51: 167-174.

Gregorich, E.G.; Greer, K.J.; Anderson, D.W.; Liang, B.C. 1998. Carbon distribution and losses: erosion and deposition effects. Soil Tillage Research 47: 291-302.

Guimarães, D.V.; Gonzaga, M.I.S.; Silva, T.O.; Silva, T.L.; Dias, N.; Matias, M.I.S. 2013. Soil organic matter pools and carbon fractions in soil under different land uses. Soil Tillage Research, 126: $177-182$.

Hancock, G.R.; Murphy, D.; Evans, K.G. 2010. Hillslope and catchment scale soil organic carbon concentration: an assessment of the role of geomorphology and soil erosion in an undisturbed environment. Geoderma 155: 36-45.

Ito, T.; Shoji, S.; Shirato, Y.; Ono, E. 1991. Differentiation of a spodic horizon from a buried A horizon. Soil Science Society of America Journal 55: 438-442.

Jasiewicz, J.; Stepinski, T.F. 2013. Geomorphons: a pattern recognition approach to classification and mapping of landforms. Geomorphology 182: 147-156.

Kosmas, C.; Gerontidis, S.; Marathianou, M. 2000. The effect of land use change on soils and vegetation over various lithological formations on Lesvos (Greece). Catena 40: 51-68.
Kreznor, W.R.; Olson, K.R.; Banwart, W.L.; Johnson, D.L. 1989. Soil, landscape, and erosion relationships in a Northwestern Illinois watershed. Soil Science Society of America Journal 53: 1763-1771.

Lal, R. 2004. Soil carbon sequestration impacts on global climate change and food security. Science 304: 1623-1627.

McKeague, J.A. 1968. Humic-fulvic acid ratio, $\mathrm{Al}, \mathrm{Fe}$ and $\mathrm{C}$ in pyrophosphate extracts as criteria of $\mathrm{A}$ and $\mathrm{B}$ horizons. Canadian Journal of Soil Science 48:27-35.

Menezes, M.D.; Silva, S.H.G.; Owens, P.R.; Curi, N. 2013. Digital soil mapping approach based on fuzzy logic and field expert knowledge. Ciência e Agrotecnologia 37: 287-29.

Mirave, J.P.; Orioli, G.A. 1987. Edaphic mobility of complete humic acid and fractions of high and medium molecular weight. Plant and Soil 104: 169-174.

Moore, I.D.; Gessler, P.E.; Nielsen, G.A.; Peterson, G.A. 1993. Soil attribute prediction using terrain analysis. Soil Science Society of America Journal 57: 443-452.

Mueller, T.G.; Pierce, F.J. 2003. Soil carbon maps: enhancing spatial estimates with simple terrain attributes at multiple scales. Soil Science Society of America Journal 67: 258-267.

Pei, T.; Qin, C.; Zhu, A.; Yang, L.; Luo, M.; Li, B.; Zhou, C. 2010. Mapping soil organic matter using the topographic wetness index: a comparative study based on different flow-direction algorithms and kriging methods. Ecological Indicators 10: 610619.

Rayment, G.E.; Lyons, D.J. 2011. Carbon. p. 65-92. In: Rayment, G.E.; Lyons, D.J., eds. Soil chemical methods: Australasia. CSIRO, Melbourne, Australia.

Schaetzl, R.J.; Anderson, S.N. 2005. Soils: Genesis and Geomorphology. Cambridge University Press, Cambridge, UK.

Schnitzer, M. 2000. A lifetime perspective on the chemistry of soil organic matter. Advances in Agronomy 68 : 3-58.

Silva, E.A.; Gomes, J.B.V.; Araújo Filho, J.C.; Vidal-Torrado, P.; Cooper, M.; Curi, N. 2012a. Morphology, mineralogy and micromorphology of soils associated to summit depressions of the Brazilian Northeastern coastal plains. Ciência e Agrotecnologia 34: 507-517.

Silva, E.A.; Silva, C.A.; Silva, I.R.; Marques, J.J.G.S.M.; Araújo, E.F.; Carvalho, S.A.; Silva, S.H.G.; Curi, N. 2012b. Carbon fractions in toposequences of soils under eucalyptus with different use history. Revista Brasileira de Ciência do Solo 36: 1167-1178 (in Portuguese, with abstract in English).

Soil Survey Staff. 1999. Soil Taxonomy: A Basic System of Soil Classification for Making and Interpreting Soil Surveys. 2ed. USDA-SCS, Washington, DC, USA. (Handbook, 436)

Stevenson, F.J. 1994. Humus Chemistry: Genesis, Composition, Reactions. 2ed. John Wiley, New York, NY, USA.

Vandenbygaart, A.J; Kroetsch, D.; Gregorich, E.G.; Lobb, D. 2012. Soil C erosion and burial in cropland. Global Change Biology 18: 1441-1452.

Yeomans, J.C.; Bremner, J.M. 1988. A rapid and precise method for routine determination of organic carbon in soil. Communications in Soil Science and Plant Analysis 19: 14671476. 